\title{
Morphological and Molecular (SSR) Analysis of Old Apple Cultivars
}

\author{
Ildikó KIRÁLY*, Róbert REDECZKI루 Éva ERDÉLYI², Magdolna TÓTH ${ }^{1}$ \\ ${ }^{1}$ Corvinus University of Budapest, Faculty of Horticultural Science, Department of Pomology, Villányi út 29- \\ 43, Budapest1118,Hungary; ildiko.kiraly@uni-corvinus.hu ( ${ }^{*}$ correspondingauthor) \\ ${ }^{2}$ Budapest Business School, College of Commerce, Catering and Tourism, Institute of Economics \\ and Methodology, Alkotmány utca 9-11, Budapest 1054, Hungary
}

\begin{abstract}
Investigations were made on the morphological traits of the flowers, shoots and fruits of five apple cultivars in the Batul group and four in the Sóvári Group, in order to prepare UPOV (Union Internationale pour la Protection des Obtentions Végétales) descriptions of these cultivars. Marker analysis involving 12 microsatellite primers was performed to identify 13 genotypes. All the analytical methods indicated that 'Zöld batul' could be clearly distinguished from the other 'Batul' selections, suggesting that it is an independent cultivar distantly related to 'Batul'. Within the Sóvári Group, the cultivars could be clearly distinguished from each other on the basis of morphological and molecular analysis. The variants of 'Beregi sóvári' collected in the United Kingdom and in Sub-Carpathia cannot be considered to be the same cultivar. The genotype preserved in the UK National Apple Collection at Brogdale should be considered to be an unknown cultivar. The present examinations demonstrated that a combination of morphological and genetic analyses provides a more reliable identification of apple genotypes than pomological descriptions or genetic analysis alone.
\end{abstract}

Keywords: discriminant analysis, Malus $\times$ domestica, microsatellite, UPOV

\section{Introduction}

Within the framework of the Hungarian apple breeding programme (Tóth et al., 1994), one of the main tasks is to collect, select, evaluate and preserve genetic resources. Of the old genotypes known to exist in the Carpathian Basin, almost 200 local cultivars have been collected in the department's gene bank over the last two decades. As in other parts of Europe (Kellerhalls et al., 2012; Nybom et al., 2012; Sestras, 2003a, 2003b), studies of these have been made in Hungary, and old cultivars with good resistance and acceptable quality have been selected (Tóth et al., 2005a).

Some of the cultivars found in the gene bank could be of use not only in breeding, but also in organic farming, so there is a great need for the re-evaluation of the old apple cultivars. Some of the old apple varieties have become well adapted to the soil and climatic conditions of the Carpathian Basin producing good yields and highly appreciated fruit quality (Mitre et al., 2009). Among these cultivars, particular importance is attached to those indicated by earlier authors to belong to the Batul and Sóvári Groups, which were analysed as the basis for new cultivar descriptions.

'Batul' (synonym: 'Patul') is one of the most attractive and widespread of the old apple cultivars from Transylvania. Cultivar descriptions of the basic 'Batul' do not differ to any great extent (Angyal, 1926; Bereczki, 1882; Bordeianu et al., 1964; Oberdieck and Lucas, 1860; Stoll, 1888).
Several variants of 'Batul' are known in Transylvania: 'Zöld batul', 'Fehér batul', 'Szögletes batul', 'Mosolygós' or 'Piros batul', 'Bordás batul', 'Félig piros batul', 'Sárga batul', 'Édes batul', 'Tüzes batul', 'Nagy batul', 'Selyem batul' (Brózik and Regius, 1959; Molnár, 1898; Tóth and Szani, 2004). While the pomological descriptions of the basic variety are undeniably reliable, the descriptions of the variants are less clear. In some descriptions the headword is 'Batul', but at the end of the description the author notes that it refers to 'Mosolygós batul'. No clear guidelines are given as to the difference between the two cultivars.

The collective name Sóvári covers a whole group of cultivars, as a great number of forms are to be found. The best known of these are 'Nemes sóvári', 'Beregi sóvári' and 'Daru sóvári'. Other variants can be found in certain locations: 'Közönséges sóvári' (syn.: 'Sovari commun’), 'Csíkos sóvári' (syn.: 'Sovari pestrit'), 'Piros sóvári' (syn.: 'Sovari rosu'), 'Zöld sóvári', 'Téli sóvári’ (Bereczki, 1877, 1884; Bordeianu et al., 1964). German pomologists (Oberdieck and Lucas, 1860) and the Austrian pomologist Stoll (1988) were introduced to 'Daru sóvári' (syn: 'Daru alma') by the Hungarian pomologist Máté Bereczki.

It is important to examine old apple cultivars because the pomological descriptions available for old cultivars are not uniform. Many collections of cultivar descriptions use several names for one cultivar, or the same name for several cultivars. Number codes, such as that elaborated in Hungary by Brózik (1974), are useful in that they allow uniformly compiled descriptions to be made. Nowadays, 
270

in most cases the guidelines given by UPOV (Union Internationale pour la Protection des Obtentions Végétales) or $\mathrm{CPVO}$ (Community Plant Variety Office) are applied, as the brief descriptions and number codes provide sufficient information for cultivars to be differentiated. They have the advantage that they can be applied on an international scale and enable the results obtained by different research teams to be easily compared.

In addition to morphological descriptions, identification is increasingly made at the DNA level, most frequently using microsatellite ( $S S R=$ simple sequence repeats) markers. Almost 300 microsatellite markers are now available for apple (Gianfranceschi et al., 1998; Liebhard et al., 2002; Silfverberg-Dilworth et al., 2006). SSR markers have been used for the assessment of genetic diversity in germplasm collections (Potts et al., 2011), for cultivar identification (Laurens et al., 2004) and for parent and pedigree identification (Király et al., 2009).

Until recently, genetic and morphological analysis and pomological descriptions have been used separately for the identification of old apple varieties. Work was begun in the department in 2007 to determine whether the use of parallel genetic, morphological and biological analyses and the calculation of statistical correlations between the results would allow variants or independent genotypes within a given cultivar group to be distinguished with greater reliability. The purpose of the present work was to identify and characterise apparently different genotypes from the Batul Group and the Sóvári Group. This is of importance partly because the majority of pomologists give a description of the basic cultivar, but then simply list the cultivar variants without providing precise descriptions. In addition, for cultivars that were propagated for a long period by growers, valuable bud mutations or seedlings may have been selected, the genotypes of which may be proved by morphological and genetic analysis to have become independent cultivars. This paper contains the morphological traits of the flowers, shoots and fruit of the cultivars or selections from the Groups of Batul and Sóvári found in the department's apple collection. Molecular analysis aimed at differentiating between the genotypes involved 12 microsatellite loci exhibiting a large degree of polymorphism.

\section{Material and methods}

\section{Morphological analysis}

Morphological analysis was performed on four trees of each genotype in the gene bank of the Department of Pomology, Corvinus University of Budapest, in 2009. The trees, on M106 rootstocks, were planted in 2001. The collection is located in Soroksár $\left(47^{\circ} 40^{\prime} \mathrm{N}, 19^{\circ} 15^{\prime} \mathrm{E}\right)$, in the north-west part of the Great Plain, on the flood plain of the River Danube, so most of the soils were formed on calcareous sandy alluvial deposits. The climate is dry, with frequent droughts.
Five cultivars or selections of Batul Group and four of Sóvári Group were included in the morphological analyses. In 1948 Mátyás Mohácsy sent Hungarian apple varieties from the university's collection to the UK National Apple Collection at Brogdale in Kent. The present investigations were made on a number of cultivars sent back from Brogdale ('Batul' Sel. 1, 'Beregi sóvári' Sel. 1, 'Daru sóvári'), and on cultivars collected in small orchards in Sub-Carpathia, Ukraine ('Batul' Sel. 2 and 3, 'Beregi sóvári' Sel. 2, 'Nemes sóvári') and in Transylvania, Romania ('Mosolygós batul', 'Zöld batul') (Tóth, 2005).

The morphological description was compiled according to the UPOV TG/14/9 guidelines (2005). A total of 42 morphological (leaf: 7; flower: 4; fruit: 31) and 3 phenological traits were examined and described. Twenty flowers, leaves and fruits were evaluated for each cultivar. The flower diameter was measured after pressing the petals into a horizontal position, and this measurement was used to classify the cultivars in size categories. In addition to the diameter, the following flower characteristics were recorded: predominant colour at the balloon stage, arrangement of petals, and position of stigmas relative to anthers. The leaves for analysis were picked at the end of intensive shoot growth, from the middle third of vigorous shoots. Measurements were made on the length and width of the leaf blade and the length of the petiole. The leaf shape index was calculated from the length/width ratio. A record was made of the attitude of the leaf blade in relation to the shoot, the pubescence on the lower side of the leaf blade, and the incision of the margins. The fruit were characterised using a total of 31 morphological characteristics.

The morphological traits were compared by the analysis of variance and the cultivars were grouped by the Tukey method using the PASW 18.0 program package. Dendrogram was created on the basis of Euclidean distances with the software PAST (Hammer et al., 2001).

\section{Marker analysis}

In addition to the cultivar variants used for the above analyses, samples of 'Fehér batul', 'Sóvári nobil', Téli sóvári' and 'Zöld sóvári' from either our own, or a private collection in Southern Hungary, were included in the genetic analysis.

DNA was isolated from young leaves using a DNeasy Plant Mini Kit (Qiagen). PCR was performed in a final volume of $25 \mu \mathrm{l}$, containing about $25 \mathrm{ng}$ of genomic DNA and $0.2 \mu \mathrm{M}$ of each primer in DreamTaq $q^{\text {Tm }}$ Green PCR Master Mix (2X) (Fermentas), using an Applied Biosystems Thermal Cycler 2720. The 12 primer pairs were $\mathrm{CH} 01 \mathrm{f02}, \mathrm{CH} 01 \mathrm{~h} 01, \mathrm{CH} 02 \mathrm{c} 02 \mathrm{a}, \mathrm{CH} 02 \mathrm{c09}, \mathrm{CH} 03 \mathrm{~g} 07$, $\mathrm{CH} 04 \mathrm{e} 03, \mathrm{CH} 05 \mathrm{~d} 11, \mathrm{CH} 05 \mathrm{e} 03, \mathrm{CH} 02 \mathrm{c} 11, \mathrm{CH} 02 \mathrm{~d} 08$, $\mathrm{CH} 03 \mathrm{a} 02$ and $\mathrm{CH05c04}$ (Gianfranceschi et al., 1998; Liebhard et al., 2002). The amplification conditions were: $94^{\circ} \mathrm{C} 2^{\prime} ; 94^{\circ} \mathrm{C} 20^{\prime \prime}, 56^{\circ} \mathrm{C} 30^{\prime \prime}, 72^{\circ} \mathrm{C} 1^{\prime}, 35 \times ; 72^{\circ} \mathrm{C} 5^{\prime}$ (Galli et al., 2005). To determine the exact size of the different 
fragments, the PCR products amplified by fluorescently labelled forward primers (JOE; FAM) were analysed in an automated sequencer (ABI Prism 3100 Genetic Analyzer; Applied Biosystems). Band scoring was carried out using Genographer 1.6 software. For the cluster analysis, each detected allele was scored as present ( 1 ) or absent ( 0$)$. The UPGMA (Unweighted Pair Group Method with Arithmetic mean) algorithm was used to construct a dendrogram based on Dice's similarity coefficient (Dice, 1945) with the software PAST.

\section{Results}

\section{Morphological traits}

\section{Batul Group}

It was not possible to differentiate among the genotypes 'Batul' Sel. 1, Sel. 2, Sel. 3 and 'Mosolygós batul' on the basis of leaf traits alone. Concerning the length of leaf blade and petiole, 'Zöld batul' however, differed significantly from the other variants on the basis of quantitative traits (Tab. 1). Within the Batul Group very few differences were found for the flowers. The predominant colour of the flowers at the balloon stage was dark pink for all the cultivars, the arrangement of the petals was overlapping, and the stigmas and anthers were on the same level (data not shown). As regards the diameter of flowers, cultivars of Batul Group were separated in three groups using the Tukey method. Most of the cultivars had large and obloid or globose fruit, while those of 'Zöld batul' were regular very large and globose or slightly elongated globose in shape. Overall, there were no great differences between the cultivars in the Batul Group based on the morphological traits of the fruit, except in the case of 'Zöld batul', which could be clearly distinguished from the others in the course of analysis of variance.

Data grouping using the Tukey method (Tab. 1) revealed that the 'Batul' Sel. 1, Sel. 2 and Sel. 3 collected from three different locations and the 'Mosolygós batul' genotype formed a single large group, while 'Zöld batul' could be clearly distinguished from the other members of the cultivar group.

\section{Sóvári Group}

During the characterisation of the leaves, clear differences were observed among the 'Beregi sóvári' Sel. 1, Sel. 2, 'Daru sóvári' and 'Nemes sóvári' in the incisions on the leaf margins (data not shown). The cultivars could be divided into two groups on the basis of the length of leaf blade and petiole (Tab. 1). The statistical analysis of the fruit height and width data also detected significant differences between all the cultivars on the basis of pairwise comparison. Among the Sóvári cultivars investigated, the fruit was conical for 'Daru sóvári', globose for 'Nemes sóvári' and 'Beregi sóvári' Sel. 2, and obloid for 'Beregi sóvári' Sel. 1. With regard to the flower and fruit characteristics, 'Beregi sóvári' Sel. 1 could be clearly distinguished from 'Beregi sóvári' Sel. 2.

\section{Evaluation using the UPOV number code}

It could be seen from the data analysis that the five measured traits were not sufficient to give an unambiguous answer to the question of whether the various Batul and Sóvári selections were identical. In addition to the descriptive characterisation, the UPOV number code facilitates the statistical analysis of non-measurable traits. The dendrogram compiled on the basis of 45 characteristics (Fig. 1) gave a similar result to the quantitative traits: 'Zöld batul' proved to be quite distinct from the other Batul selections, which formed a single group. The dendrogram also clarified the separation of the cultivars within the Sóvári Group, which was somewhat ambiguous in the case of the five measured traits. Analysis of variance and hierarchical cluster analysis confirmed the wide differences between the individual members of the Sóvári Group. The two selections of 'Beregi sóvári' were again in sharp contrast to each other.

Tab. 1. Data recorded on leaves, flowers and fruits in 2009

\begin{tabular}{|c|c|c|c|c|c|c|}
\hline Cultivar & $\begin{array}{l}\text { Length of } \\
\text { leaf blade } \\
(\mathrm{mm})\end{array}$ & $\begin{array}{l}\text { Width of } \\
\text { leaf blade } \\
(\mathrm{mm})\end{array}$ & $\begin{array}{l}\text { Length of petiole } \\
(\mathrm{mm})\end{array}$ & $\begin{array}{c}\text { Diameter } \\
\text { of flower } \\
(\mathrm{mm})\end{array}$ & $\begin{array}{l}\text { Height of fruit } \\
(\mathrm{mm})\end{array}$ & $\begin{array}{c}\text { Diameter } \\
\text { of fruit } \\
(\mathrm{mm})\end{array}$ \\
\hline \multicolumn{7}{|c|}{ Batul cultivars and selections ${ }^{a}$} \\
\hline 'Batul' Sel. 1. & $66.55 \pm 2.33 \mathrm{a}$ & $51.6 \pm 2.23 \mathrm{ab}$ & $22.35 \pm 1.27 \mathrm{a}$ & $39.2 \pm 3.12 \mathrm{a}$ & $67.20 \pm 5.62 \mathrm{~b}$ & $78.25 \pm 5.44 \mathrm{ab}$ \\
\hline 'Batul' Sel. 2. & $67.85 \pm 4.03 \mathrm{a}$ & $53.15 \pm 3.69 \mathrm{~b}$ & $22.75 \pm 2.10 \mathrm{a}$ & $42.6 \pm 2.87 \mathrm{~b}$ & $62.8 \pm 4.48 \mathrm{a}$ & $74.6 \pm 3.86 \mathrm{a}$ \\
\hline 'Batul' Sel. 3. & $69.35 \pm 3.48 \mathrm{a}$ & $53.2 \pm 1.88 \mathrm{~b}$ & $21.75 \pm 1.48 \mathrm{a}$ & $44.6 \pm 3.66 \mathrm{~b}$ & $62.2 \pm 3.64 \mathrm{a}$ & $74.3 \pm 3.74 \mathrm{a}$ \\
\hline 'Mosolygós batul' & $66.35 \pm 3.91 \mathrm{a}$ & $53.1 \pm 2.81 \mathrm{~b}$ & $20.95 \pm 2.26 \mathrm{a}$ & $36.7 \pm 3.11 \mathrm{a}$ & $63.95 \pm 4.44 \mathrm{ab}$ & $75.85 \pm 3.96 \mathrm{a}$ \\
\hline 'Zöld batul' & $81.4 \pm 5.19 b$ & $50.4 \pm 3.65 \mathrm{a}$ & $27.95 \pm 2.96 \mathrm{~b}$ & $47.55 \pm 2.19 \mathrm{c}$ & $74.35 \pm 5.98 \mathrm{c}$ & $80.25 \pm 5.29 \mathrm{~b}$ \\
\hline \multicolumn{7}{|c|}{ Sóvári cultivars and selections $\mathrm{s}^{\mathrm{a}}$} \\
\hline ‘Beregi sóvári’ Sel. 1. & $82.8 \pm 5.12 \mathrm{a}$ & $58.55 \pm 4.66 \mathrm{ab}$ & $18.65 \pm 1.46 \mathrm{a}$ & $39.55 \pm 3.61 \mathrm{a}$ & $48.95 \pm 4.22 \mathrm{a}$ & $68.4 \pm 3.07 \mathrm{a}$ \\
\hline 'Beregi sóvári’ Sel. 2. & $79.9 \pm 4.89 \mathrm{a}$ & $55.4 \pm 4.82 \mathrm{a}$ & $21.65 \pm 1.93 \mathrm{~b}$ & $47.9 \pm 3.09 b$ & $63.35 \pm 3.80 \mathrm{c}$ & $76.35 \pm 3.90 \mathrm{~b}$ \\
\hline 'Daru sóvári' & $91.8 \pm 6.10 \mathrm{~b}$ & $66.85 \pm 5.16 \mathrm{c}$ & $17.55 \pm 1.93 \mathrm{a}$ & $52.15 \pm 2.94 \mathrm{c}$ & $58.45 \pm 4.50 \mathrm{~b}$ & $71.5 \pm 4.57 \mathrm{a}$ \\
\hline 'Nemes sóvári' & $87.7 \pm 4.28 \mathrm{~b}$ & $60.15 \pm 4.31 \mathrm{~b}$ & $18.8 \pm 1.51 \mathrm{a}$ & $49.6 \pm 3.52 b c$ & $73.2 \pm 5.41 \mathrm{~d}$ & $87.55 \pm 5.36 c$ \\
\hline
\end{tabular}

${ }^{a}$ Statistical analyses were performed separately for the Batul and Sóvári cultivars; values with the same letter indicate cultivars that there is no significant difference at $95 \%$ confidence 
Distance

$\vec{P} \quad \vec{N} \quad \vec{i} \quad \infty \quad i \quad+\quad \sim$

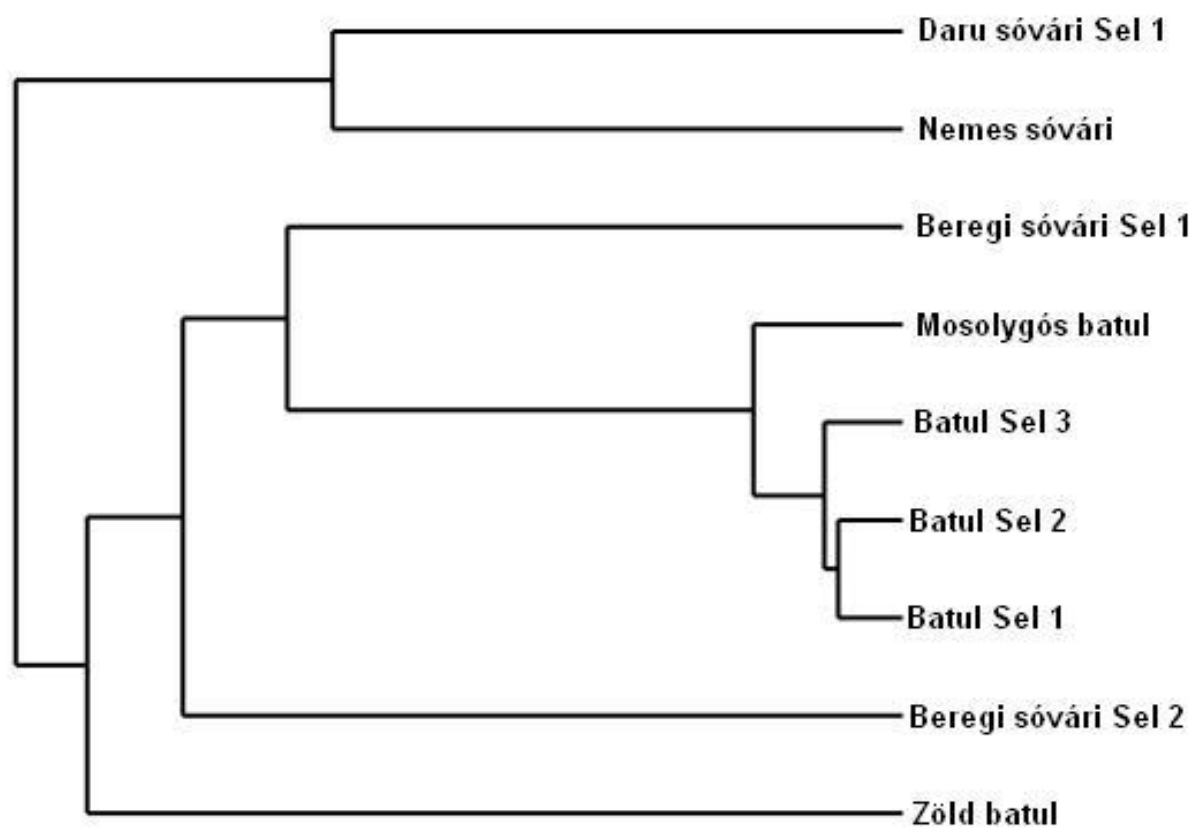

Fig. 1. UPGMA cluster analysis based on Euclidean distances derived from 45 UPOV characteristics of 'Batul' and 'Sóvári' cultivars and selections

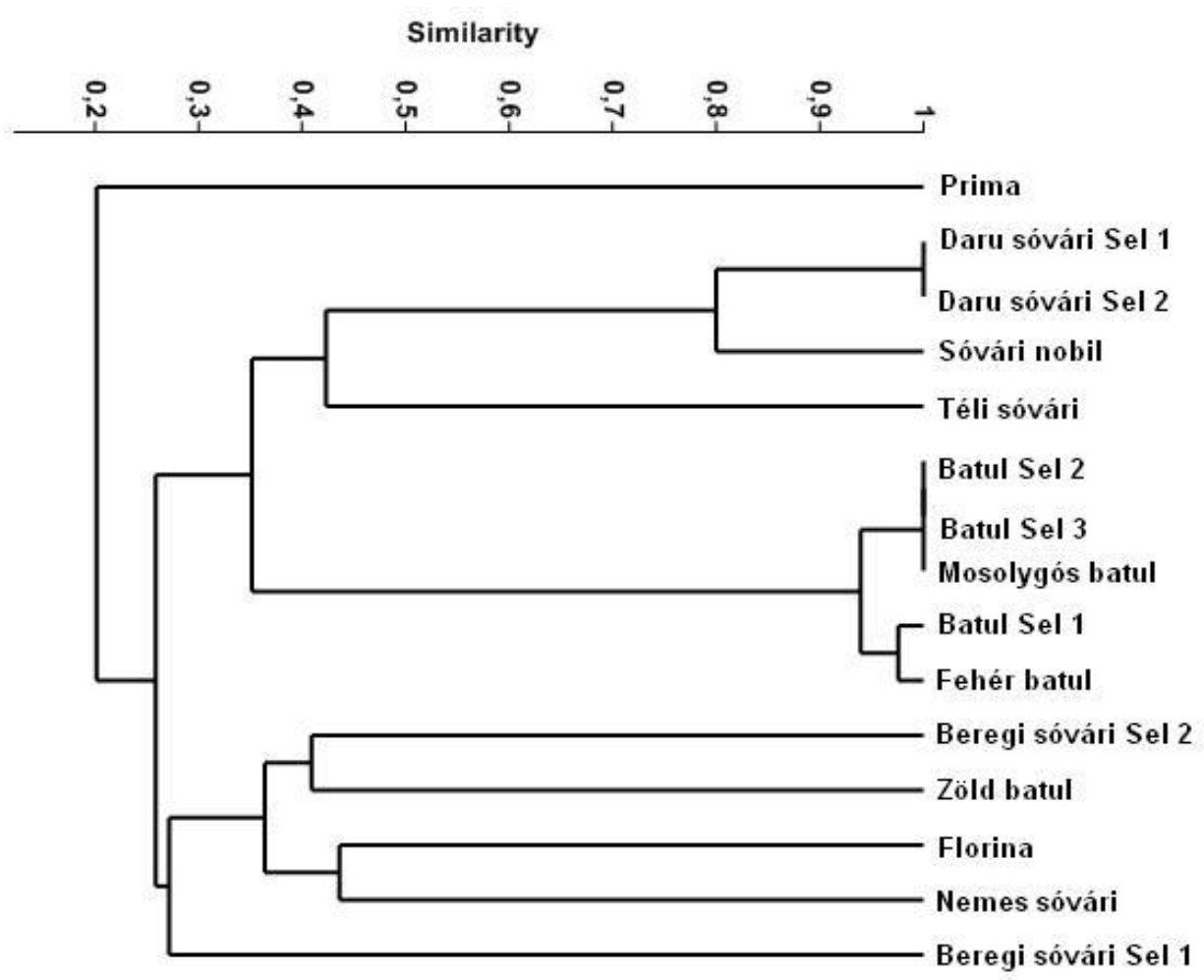

Fig. 2. UPGMA cluster analysis based on Dice genetic distances for 12 SSR loci in 'Batul' and 'Sóvári' cultivars and selections 
Tab. 2. Fruit height and diameter of 'Batul' and 'Sóvári' cultivars in the literature

\begin{tabular}{|c|c|c|c|c|c|c|c|c|c|c|c|c|c|c|c|}
\hline & \multicolumn{5}{|c|}{ 'Batul' } & \multicolumn{4}{|c|}{ 'Mosolygós batul' } & \multicolumn{4}{|c|}{ 'Nemes sóvári' } & \multicolumn{2}{|c|}{$\begin{array}{c}\text { 'Beregi sóvári' } \\
\text { Sel. } 2 \\
\end{array}$} \\
\hline & 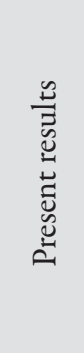 & 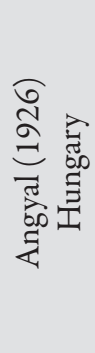 & 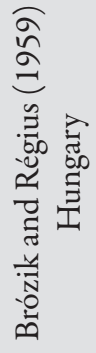 & 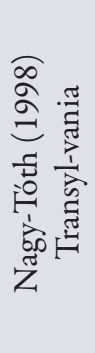 & 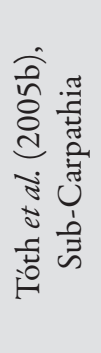 & 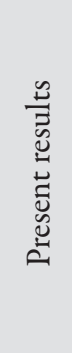 & 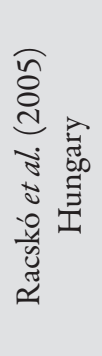 & 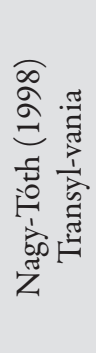 & 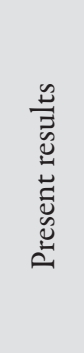 & 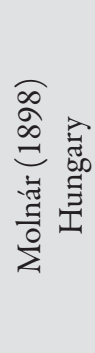 & 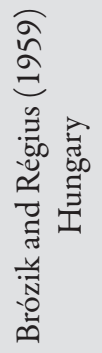 & 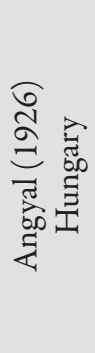 & 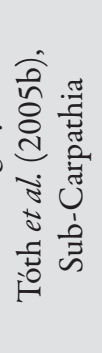 & 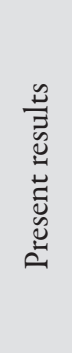 & 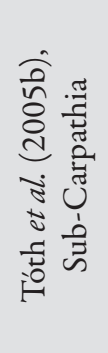 \\
\hline $\begin{array}{l}\text { Fruit: height } \\
(\mathrm{mm})\end{array}$ & $62-67$ & 64 & $45-50$ & $55-65$ & 49 & 64 & 60 & $47-53$ & 73,2 & 60 & $50-52$ & 60 & 50 & 63 & 52 \\
\hline $\begin{array}{l}\text { Fruit: diameter } \\
\qquad(\mathrm{mm})\end{array}$ & $74-78$ & 72 & $52-65$ & $60-75$ & 60 & 76 & 70 & $55-60$ & 87,55 & 70 & $58-63$ & 70 & 63 & 76 & 66 \\
\hline $\begin{array}{l}\text { Fruit: height/ } \\
\text { diameter ratio }\end{array}$ & $\begin{array}{l}0.84- \\
0.86\end{array}$ & 0.88 & $\sim 0.81$ & $\sim 0.88$ & 0.8 & 0.84 & 0.85 & $\sim 0.87$ & 0.83 & 0.86 & 0.84 & 0.86 & 0.80 & 0.83 & 0.80 \\
\hline
\end{tabular}

\section{Results of marker analysis}

The dendrogram compiled on the basis of the Dice index (Fig. 2) made it clear that, with the exception of 'Zöld batul', all the Batul selections formed a single group. No distinction could be made between 'Batul' Sel. 2 and 3 and 'Mosolygós batul', while 'Batul' Sel. 1 and 'Fehér batul' were slightly separated from them. By contrast, only a single allele at each of four loci (CH01h01, CH04e03, CH02d08, $\mathrm{CH} 05 \mathrm{c04}$ ) in 'Zöld batul' exhibited any similarity to the other 'Batul' types investigated and this genotype was in a completely different group on the dendrogram. 'Daru sóvári', 'Sóvári nobil' and 'Téli sóvári' formed another group, though they were at some distance from each other. 'Nemes sóvári', Beregi sóvári' Sel. 2, 'Zöld batul' and the control genotype 'Florina' formed the third group, which showed hardly any similarity to each other due to the large genetic distance. 'Beregi sóvári' Sel. 1 could not be put into any of the groups.

\section{Discussion}

Very few precise measurement data have been reported for the fruit of 'Batul'. The data provided by seven authors were compared with the present measurements in Tab. 2 , and no great differences could be observed. Tóth et al. (2005b) and Nagy-Tóth (1998) examined fruit originating from scattered orchards in Transylvania and SubCarpathia, which could explain the smaller size. The shape index, however, was much the same in all cases (0.8-0.85) and confirmed that the fruit were slightly flattened globose in shape. The fruit grown in Soroksár were also larger in the case of 'Nemes sóvári' and 'Beregi sóvári' than those originating from scattered orchards in Sub-Carpathia (Tab. 2).

Only some of the variants within the Batul Group could be distinguished with the help of marker analysis. It would be worth including other variants in the analysis. None of the Sóvári variants proved to be identical, so they can all be regarded as separate cultivars. The two variants of 'Beregi sóvári' were also found to differ. Wichmann et al. (2007) investigated the cultivars 'Nyári sóvári' and 'Puha sóvári', and although SSR values are often not directly comparable between different studies, they did not detect the same fragment lengths at the equivalent loci as have been found in the present work.

When analysing the $S$-allele composition of old Hungarian apple varieties, Halász et al. (2011) found 'Nemes sóvári' to be triploid in terms of both the $S$-allele and the ploidy level. This is in agreement with the data obtained by means of microsatellite marker analysis in the present work.

The best cultivars in the two cultivar groups can continue to be recommended for plantation in private gardens and organic farms. Investigations into the disease resistance of these cultivars showed that 'Batul' and 'Nemes sóvári' were not susceptible to diseases (Kása et al., 2005; Tóth et al., 2005a).

It is currently hoped to re-register a number of old cultivars in Hungary, so information on the pomological characteristics of these cultivars will soon be of key importance. Cultivars can be registered far more easily if they are submitted with a full DUS description. As in the case of peach, the intention is to check the distinctiveness of the cultivars using genetic markers, in addition to the DUS tests.

Valuable gene sources are to be found among the old cultivars in genetic resource collections. For examples, when testing old cultivars for resistance to scab the $V d$ gene was detected in an old Italian cultivar, 'Durello di Forli' (Tartarini et al., 2004), while Nybom et al. (2012) used artificial inoculation and marker analysis to search Swedish cultivar collections for cultivars resistant to fire blight. 
274

\section{Conclusions}

The UPOV number code was used to give a uniform type of objective description for the cultivars in the investigated cultivar groups. Four cultivars from the Batul Group and five from the Sóvári Group were also investigated by means of SSR marker analysis. The results indicated that the cultivar descriptions currently available should be replaced by a combination of morphological, biological and genetic analyses if apple cultivars are to be reliably distinguished.

According to the results of these complex analyses, the 'Beregi sóvári' variant re-introduced from the UK and the type collected in Sub-Carpathia can no longer be regarded as the same cultivar. Based on the relevant pomological literature, the latter proved to be the true type. The genotype of 'Beregi sóvári' preserved in the UK National Apple Collection (Morgan and Richards, 1993) should thus be considered to be an unknown cultivar.

The differences assumed to exist between the cultivar known in the pomological literature as 'Mosolygó batul' and the basic 'Batul' cultivar could not be confirmed either by morphological observations or by SSR marker analysis at 12 loci, nor did other types of 'Batul' collected from various locations differ from these cultivars. 'Zöld batul', on the other hand, exhibited no direct relationship with the 'Batul' cultivar, so this type should be registered in the future as a separate cultivar on the basis of the detailed UPOV description compiled in the present work.

\section{Acknowledgements}

Our research work could be carried out in the framework of TÁMOP 4.2.1./B-09/01/KMR/2010-0005 and VM-É-45343 projects.

\section{References}

Angyal D (1926). Pomology. Pátria Irodalmi Vállalat és Nyomdai Rt, Budapest, 25-27; 94-96 p. (in Magyar).

Bereczki M (1877). Pomological sketches. Volume I. Gyulai István nyomdája, Arad, 421-422 p. (in Magyar).

Bereczki M (1882). Pomological sketches. Volume II. Gyulai István nyomdája, Arad, 295-296 p. (in Magyar).

Bereczki M (1884). Pomological sketches. Volume III. Gyulai István nyomdája, Arad, 405-408 p. (in Magyar).

Bordeianu T, Constantinescu N, Péterfi S, Stefan N, Anghel G, Costetch M, Cvasnii D, Miron G, Oros F, Pompeius E, Trandafir V (1964). Romanian Pomology. ACAD.R.P.R., Bucharest, 432-436; 455-458; 884-890 p. (in Romanian).

Brózik S (1974). Pomology. In: Fruit-growing technology. Mezőgazdasági Kiadó, Budapest, 22-41 p. (in Magyar).

Brózik S, Régius J (1959). Cultivated fruit cultivars. Pome fruits. Apple. Mezőgazdasági Kiadó, Budapest.

Dice LR (1945). Measures of the Amount of Ecologic Association Between Species. Ecology 3:297-302.
Galli Zs, Halász G, Kiss E, Heszky L, Dobránszki J (2005). Molecular identification of commercial apple cultivars with microsatellite markers. Hort Sci 7:1974-1977.

Gianfranceschi L, Seglias N, Tarchini R, Komjanc M, Gessler C (1998). Simple sequence repeats for the genetic analysis of apple. Theor Appl Genet 96:1069-1076.

Halász J, Hegedűs A, György Zs, Pállinger É, Tóth M (2011). $S$-genotyping of old apple cultivars from the Carpathian basin: methodological, breeding and evolutionary aspects. Tree Genet Genomes 7:1135-1145.

Hammer R, Harper DAT, Ryan PD (2001). PAST: Paleontological Statistics Software Package for Education and Data Analysis. Palaeontol, Electronica 4(1):9.

Kása K, Hevesi M, Tóth M (2005). Evaluation of traditional Hungarian cultivars as sources of resistance to fire blight, Acta Hort 663:225-228.

Kellerhals M, Szalatnay D, Hunziker K, Duffy B, Nybom H, Ahmadi-Afzadi M, Höfer M, Richter K, Lateur M (2012). European pome fruit genetic resources evaluated for disease resistance. Trees 26:179-189.

Király I, Pedryc A, Halász J, Deák T, Tóth M (2009). Parent identification of Hungarian apple cultivars using SSR markers. Acta Hort 839:471-477.

Laurens F, Durel CE, Lascostes M (2004). Molecular characterization of french local apple cultivars using SSRs. Acta Hort 663:639-642.

Liebhard R, Gianfranceschi L, Koller B, Ryder CD, Tarchini R, van de Weg E, Gessler C (2002). Development and characterisation of 140 microsatellites in apple (Malus $\times$ domestica Borkh.). Mol Breed 10:217-241.

Mitre I, Mitre V, Ardelean M, Sestras R, Sestras A (2009). Evaluation of old apple cultivars grown in central Transylvania, Romania. Not Bot Horti Agrobo 37(1):235237.

Molnár I (1898). Hungarian pomology. Volume I. and II. Athenaeum Nyomda, Budapest (in Magyar).

Morgan J, Richards A (1993). The book of apples. Ebury Press, London, $187 \mathrm{p}$.

Nagy-Tóth F (1998). Old Transylvanian apples. Erdélyi Múzeum-Egyesület, Kolozsvár (in Magyar).

Nybom H, Mikicinski A, Garkava-Gustavsson L, Sehic J, Lewandowski M, Sobiczewski P (2012). Assessment of fire blight tolerance in apple based on plant inoculations with Erwinia amylovora and DNA markers. Trees 26:199-213.

Oberdieck JGC, Lucas E (1860). Journal of Pomology and Practical Fruit-Growing. Ebner and Seubert, Stuttgart, 130131 p. (in German).

Potts SM, Han Y, Khan MA, Kushad MM, Rayburn AL, Korban SS (2011). Genetic diversity and characterization of a core collection of Malus germplasm using simple sequence repeats (SSRs). Plant Mol Biol Rep doi: 0.1007/s11105011-0399-x

Racskó J, Szabó T, Soltész M, Szabó Z, Nyéki J (2005). Fruit 
morphological characteristics and inner nutrient content parameters of traditional Hungarian apple cultivars. Kertgazdaság 3:23-35 (in Magyar).

Sestras R (2003a). Response of several apple varieties to powdery mildew (Podosphaera leucotricha) attack in Central Transylvania conditions. J Central Europ Agricult 4(4):347353.

Sestras R (2003b). Response of several apple varieties to apple scab (Venturia inaequalis) attack in Central Transylvania conditions. J Central Europ Agricult 4(4):355-362.

Silfverberg-Dilworth E, Matasci CL, van de Weg WE, van Kaauwen MPW, Walser M, Kodde LP, Soglio V, Gianfranceschi L, Durel CE, Costa F, Yamamoto T, Koller B, Gessler C, Patocchi A (2006). Microsatellite markers spanning the apple (Malus $\times$ domestica Borkh.) genome. Tree Genet Genomes 2:202-224.

Stoll R (1888). Austrian-Hungarian Pomology. Klosterneuburg bei Wien (in German).

Tartarini S, Gennari F, Pratesi D, Palazzetti C, Sansavini S, Parisi L, Fouillet A, Fouillet V, Durel CE (2004). Characterisation and genetic mapping of a major scab resistance gene from the old Italian apple cultivar 'Durello di Forli'. Acta Hort 663:129-133.
Tóth M (2005). Exploring and preserving old apple cultivars of the Carpathian basin. Int J Hort Sci 3:9-13.

Tóth M, Szani Zs (2004). Traditional farming within the Carpathian basin-pomaceous fruits. Int J Hort Sci 3:15-18.

Tóth M, Rozsnyay Zs, Quang DX (1994). Apple breeding for disease resistance in Hungary, 27-30 p. In: Schmidt H, Kellerhals M (Eds.). Progress in Temperature fruit Breeding. Kluwer Academic Publishers, Dordrecht.

Tóth M, Honty K, Hevesi M (2005a). Fire blight (Erwinia amylovora) susceptibility of old Hungarian apple cultivars. Int J Hort Sci 3:35-39.

Tóth M, Balikó E, Szani Zs (2005b). Evaluation of fruit quality of old apple cultivars originating from the foot of the Carpathian Mountains, for utilization in breeding and in organic farming, Int J Hort Sci 3:15-21.

UPOV. International Union for the Protection of New Varieties of Plants (2005). Guidelines for the conduct of tests for distinctness, uniformity and stability. Apple. Technical Guideline TG/14/9. http://www.upov.int/edocs/tgdocs/ en/tg014.pdf. (accessed 04 April 2005).

Wichmann B, Galli Zs, Molnár S, Galbács Zs, Kiss E, Szabó T, Heszky L (2007). Molecular identification of old Hungarian apple varieties. Int J Hort Sci 3:37-42. 